\title{
FROM “TRADITION” TO “INTANGIBLE HERITAGE”: KRAKÓW’S NATIVITY-SCENE CRAFT
}

\section{INTRODUCTION}

In the autumn of 2018 the Nativity scene (szopka) tradition in Kraków was entered on UNESCO's Representative List of the Intangible Cultural Heritage of Humanity. The Kraków nativity-scene craft thus became the first phenomenon from Poland and the first nativity-scene craft in the world to be placed on the list. The application for inclusion was submitted by Poland's Ministry of Culture and National Heritage in 2017. Earlier, in 2014, the Kraków nativity-scene craft had appeared on the Polish Intangible Cultural Heritage List. The Historical Museum of the City of Kraków ${ }^{1}$, which has been organizing annual competitions of Kraków nativity scenes for over seventy years, acted in the role of expert in both undertakings.

Voting on inclusion of the nativity scene tradition in Kraków on the UNESCO list occurred during the $13^{\text {th }}$ session of the Intergovernmental Committee for the Safeguarding of the Intangible Cultural Heritage, which was held between November 27 and December 1, 2018 in Port Louis, Mauritius. A delegation from Poland, including four nativity-scene makers from Kraków, participated in the session and the application was accepted without reservations. In Kraków, news of the craft's acceptance aroused great enthusiasm and media interest. Celebrating the good news was postponed for a week, however, because the $76^{\text {th }}$ Kraków Nativity-Scene Competition - a convenient and natural occasion on which to publicize the news - was to begin on December 6, 2018.

As to the nativity-scene makers, I observed that waiting for the decision of the UNESCO Committee evoked different reactions among them. Many hoped for the "ennoblement" of the Kraków nativity-scene craft by UNESCO and consequently its popularization in the country and abroad, leading to potentially greater interest in the purchase of nativity scenes. Some doubted whether UNESCO would want to put its name on creations so evidently connected with Christian culture and practice. There were people for whom the Committee's decision had no particular importance, because they saw in it solely a manifestation of bureaucracy raised to the international

\footnotetext{
${ }^{1}$ Since March 1, 2019, the museum has been called the Kraków Museum.
} 
level, which was far removed from the atmosphere of nativity-scene workshops. There were also people who supported the efforts for inclusion on the list for the pure pleasure of rooting for something.

The aim of the present article is to show those moments in the history of the Kraków nativity-scene craft when a top-down cultural policy (the City of Kraków, the Ministry of Culture and National Heritage, UNESCO) had a significant impact on the tradition, the canon of the Kraków nativity scene, and the general reception of the craft. I am interested exclusively in those factors that arise directly from cultural policy, and thus I do not discuss other equally strong incentives for change originating from other sources (such as, for instance, access to art materials - their periodic deficit in the communist era and the wide range of choice in recent years, technological changes, the development of the leisure industry, etc.). I concentrate primarily on those circumstances that in my opinion left the strongest mark on the Kraków nativity-scene craft, and by that I mean the organization of competitions for the most beautiful Kraków nativity scenes and the successful attempts to have the Kraków nativity-scene craft entered first on the national heritage list and then on UNESCO's Representative List of the Intangible Cultural Heritage of Humanity.

The time that has passed since the Kraków nativity-scene tradition was entered on the UNESCO List is obviously too short to summarize and evaluate the influence of this event on the evolution of the nativity-scene tradition in Kraków. However, as the preparations lasted for a long time, and as certain arrangements would seem to have become permanent, it is possible to comment on that subject as well.

By design, the present article is critical in nature. I am not concerned to provide a detailed presentation of the history of the Kraków nativity-scene craft, which can be found in several thorough works, but rather to capture certain trends and turning points that were dictated by top-down regulations connected with the cultural policy pursued in varying periods.

The Kraków nativity-scene craft is so far the only example in Poland of local intangible heritage that, having passed through the various stages of formalization and institutionalization, has risen to the rank of "mainstream heritage" (Kocój 2019), legitimated by UNESCO. It should be stressed at the same time that the process of formalizing and promoting this heritage had begun considerably earlier, that is, in 1937, the date of the first competition for the most beautiful Kraków nativity scenes, and went on under drastically changing political and cultural circumstances (from the Second World War, when the competition did not occur but the tradition survived, through the communist era, when the authorities attempted to pressure the nativity-scene makers to remove Christmas content from the nativity scenes, to the period of numerous changes after 1989, including those connected with the digitalization of heritage).

As Chiara De Cezari (2013, p. 400), as well as Birgit Meyer and Mattijs van de Port (2018, p. 7-8), have noted, heritage is protected and developed by many institutions, of which UNESCO is the most influential. This fact, as Ewa Kocój (2019) points out, inclines cultural anthropologists to examine the processes by which these institutions shape heritage. 
In addition to the above-mentioned causes that inclined me to study this subject, there is another, an entirely personal one. From November 2017 to February 2019 I worked as a museum assistant in the Kraków Folklore and Tradition Section of the Historical Museum of Kraków. Among other things, I dealt with the organization of Kraków nativity-scene competitions, post-competition exhibitions, and the lending of nativity scenes for domestic and foreign exhibitions. During this period, I had the opportunity to observe the success of Kraków's nativity-scene makers in connection with the tradition's inclusion on the UNESCO list and to take part in numerous meetings with the craft workers. As time went by, I became increasingly convinced that the events taking place around me called for a critical description. Moreover, as a result of my collaboration on the HERILIGION international research project ${ }^{2}$, in 2018-2019 I was involved in researching cultural heritage, especially religious heritage, Kraków, and the processes of the city's formation. While the ethnographic field research that I conducted as part of the project did not directly concern nativityscene making in Kraków, the hours of conversations with my team colleagues inspired me to look at the nativity-scene craft as a heritage that is not so much replicated as continuously created ${ }^{3}$. Indeed, as Regina Bendix wrote in her 2009 article, heritage is not a ready-made, once and for all, unchangeable formula, but rather a process, a cultural practice, a heritage-in-creation (a "heritagization") ${ }^{4}$.

I distinguish, therefore, three main stages in the history of the Kraków nativityscene craft: The first is the stage prior to institutionalization, covering the oldest history of nativity-scene making; the second is the stage of institutionalization, initiated by the organization of the first competition for the most beautiful nativity scene in Kraków in 1937; and the third is the UNESCO-ization of the nativity-scene craft, inaugurated by the inclusion of the Kraków nativity-scene tradition on UNESCO's Representative List of the Intangible Cultural Heritage of Humanity.

\section{THE KRAKÓW NATIVITY-SCENE CRAFT AT PRESENT}

In her work entitled Szopka Krakowska jako zjawisko folkloru miejskiego na tle szopki europejskiej. Studium historyczno-etnograficzne [The Kraków Nativity Scene as a Phenomenon of Urban Folklore in the Context of the European Nativity

\footnotetext{
${ }^{2}$ HERA Grant, the Polish team's subject was "Poland: Past(s), Heritage(s), Identities within the Cityscape of Kraków," director Dr. hab. Anna Niedźwiedź.

${ }^{3}$ Here I would like to offer my sincere thanks to Dr. hab. Anna Niedźwiedź of the Institute of Ethnology and Cultural Anthropology of Jagiellonian University and Dr. hab. Kamila Baraniecka-Olszewska, associate professor at the Institute of Archeology and Ethnology of the Polish Academy of Sciences for their keen reading of the first version of the article and for their valuable interpretative and bibliographic suggestions, which significantly influenced the final text.

${ }^{4}$ This word does not have an exact equivalent in Polish. Most often the term "patrymonializacja" ["patrimonialization"] is used (see, for instance, Kwiecińska 2017). Małgorzata Zawiła (2019) proposes the neologism "dziedziczynienie" which is a synthesis of the words "heritage" and "making."
} 
Scene: A Historio-Ethnographic Study $]^{5}$, Anna Szałapak defines the nativity scene as follows:

"The nativity scene is a small, slender, multi-level, tower-shaped, symmetrical, richly ornamented construction, depicting the place of the birth of Jesus, the Son of God. This construction, which is made of light, perishable materials, is characterized by the piling up of miniaturized elements of Kraków's historic architecture, transformed and combined in a fantastical manner" (Szałapak 2012, p. 216).

This definition accurately reflects the appearance of a contemporary "typical" Kraków nativity scene: usually, it is a small, symmetrical tower made of wood and cardboard, covered in multicolor tinfoil, and with decorations of tinfoil and cloth ${ }^{6}$. The back of the nativity scene, which is most often flat and unadorned, remains hidden from sight. The nativity scene is usually lighted (formerly with the traditional stearine candles, today usually with LED light bulbs) and is mechanized according to the fancy of the creator. The mechanism sets in motion turntables with figures, or the figures themselves, and sometimes there are also movable elements in the architecture, such as doors or windows. The architecture of the Kraków nativity scene refers to the architecture of historical Kraków. The nativity scene, however, is not a replica of the Old Town's buildings, but rather a reference to selected elements of their architecture, according to the ideas, skills, and sensibility of the maker. The central tower of the nativity scene is often the highest tower of Kraków's St. Mary's Basilica, but not infrequently various elements of Wawel Castle might be reproduced

${ }^{5}$ In addition to the above-cited book by Szałapak (2012), which is the broadest study, there are several dozen works on the Kraków nativity scenes. The most important are (chronologically) the following: Krupski 1904; Reinfuss 1958; Płatek 1971; Fryś-Pietraszkowa 1972; Ludwikowski, Wroński 1973; Wroński 1978; Rydel 1983; Barczewski 2005; Oleszkiewicz 2008 a, b; Kwiecińska, Niechaj 2012; Barczewski 2015; Niechaj [publication proposal] 2017; and Kwiecińska 2017. Most of these are works written by museologists, who are either ethnographers or historians by education; the work by the nativity-scene maker, Wiesław Barczewski, deserves a special mention. It should be emphasized that the above list contains quite varied publications, not only in regard to form but also subject (the history of the Kraków nativity scenes, the Kraków nativity scene as a literary text, the Kraków nativity scene as an artefact, the history of the competition for most beautiful Kraków nativity scene, the silhouette of Kraków nativity scenes, the role of the Historical Museum of the City of Kraków in safeguarding the Kraków nativity-scene craft). It is worth noting that in general, these are not emotionless reflections on the subject of the Kraków nativity scenes - on the contrary, often the authors do not hide their passion for the craft, but the fact does not interfere with the scholarly nature of their arguments. Much information on the subject of the history of the Kraków nativity scenes is provided by numerous exhibition catalogs and by brochures distributed in connection with the nativity-scene exhibitions in Kraków, elsewhere in Poland, and abroad. They are complemented by press and television interviews, recordings, films, articles, and press notes; the applications and documents accompanying succeeding editions of the competition for the most beautiful Kraków nativity scene; the action "For the Nativity Scenes" and the connected cultural events, such as the walk on January 6; auctions of the nativity scenes; the inclusion of the Kraków nativity-scene tradition on the Representative List; and research and documentary projects conducted by the Kraków Museum within the framework of grants from the Ministry of Culture and National Heritage. Some of the texts mentioned further a definite heritage policy in regard to the nativity scenes - they serve as illustrative material in the further part of my article.

${ }^{6}$ Of course, at times there are also nativity scenes that appear atypical, either in form or material - as will be discussed below - but here I am describing the most common types. 
(particularly Sigismund's Chapel), or elements of the Cloth Hall or Florian Gate, or of the numerous churches and tenement houses located in the Old Town or in the Kazimierz or Podgórze districts. It is thus often said that the "Kraków nativity scene is Kraków in a nutshell." Reference to Kraków's unique architecture, the tower form of the nativity scenes, and the use of tinfoil, define the "Cracovian-ness" of the nativity scenes and distinguish the Kraków nativity scene from the equally famous Neapolitan or Spanish nativity-scene crafts ${ }^{7}$. The main aim of professional nativity-scene makers is to reflect Kraków's architecture well.

Every new idea for a nativity scene is actually an architectonic idea (but also, as I will argue below, an ideological one). In this case, innovation consists in the use of new architectonic inspirations (for instance, elements that appear rarely in Church nativity scenes, such as the Markowski family's "Kazimierz nativity scene" of 2018, or Filip Fotomajczyk's scene of 2017 with elements of Kraków's modernist architecture). From the perspective of the viewer, it is the rare architecture that is most attractive in a nativity scene. For a Cracovian, or people who are familiar with Kraków's architecture, the nativity scene is a collection of puzzles - "where is that from?" The public enjoys solving these riddles in post-competition exhibitions.

The figures that populate the nativity scene are also important, though. Above all, there is the Holy Family, without which the Kraków nativity scene would not be a Christmas craft, but there are also other figures taken from the Gospels or Church tradition (the Three Kings, the shepherds, the angels). The figures might be historical (Poland's kings and leaders, the heroes of national uprisings, Kraków saints), or legendary (the Wawel dragon), or characteristic of folk culture (Death, the Devil, Herod, couples in Cracovian or mountain-folk costumes, Kraków flower-sellers, the Fowler Brotherhood, the Lajkonik and his procession, and Pan Twardowski on a rooster or on the moon). The figures may also be contemporary (John Paul II; the staff of the Kraków Historical Museum, such as the museum's director, Anna Szałapak, an ethnologist and legendary performer in the 'Piwnica pod Baranami' cabaret; or pop-culture stars such as football players or singers). Many of these figures are persons with a Kraków background; some are known only locally, while others are familiar throughout the country.

The architecture, the choice of figures, the movement, the captions, the decoration, the symbols, all contribute to the narrative level of the nativity scene, which is often accompanied by a deep symbolic message. It should be emphasized that nativity-scene makers are not infrequently reacting to current, topical events. In this sense, the nativity scene is often a summary of the past year, extracting from it what is most important, especially from the viewpoint of a Cracovian, a Catholic, and a patriot ${ }^{8}$. For example, in the nativity scenes of recent years, the makers often referred

${ }^{7}$ It should be emphasized at the same time that currently the makers of Kraków nativity scenes are not exclusively inhabitants of Kraków but persons from all over Poland and even from abroad.

8 This "viewpoint" need not coincide with personal convictions or worldview of the maker. On the other hand, there is always recognition of Kraków as a city that played an important role in Poland's history, in which patriotic and religious traditions are very strong (and often interpenetrating), and 
to the 100th anniversary of Poland's independence (1918-2018), the inclusion of the Kraków nativity-scene tradition on the UNESCO list, or the 110th anniversary (in 2017) of the death of Stanisław Wyspiański, a writer of the Young Poland period. Often the narrative level reveals not only the nativity-scene makers' technical skills but also their unusually broad historical knowledge, which enables them, for instance, to render the historical costumes of their figures in detail.

The Kraków nativity scene brings Christmas into the Kraków scenery, and at the same time the Kraków presented in the nativity scene is a mythologized and elevated city, without the least element of inferior quality or ugliness, illuminated in gold foil, full of religious and patriotic symbols, full of color, full of high rites and ceremonies - fairy-tale like. As Magdalena Kwiecińska writes, "Their [the nativityscene makers - ASM] works are a kind of story about all that gives the town its genius loci" (Kwiecińska 2016, p. 174). The Christmas scene itself is rendered with a kind of subtlety and mysteriousness: the Holy Family is placed on the second story of the scene, in a special nook very often covered with a replica of the Sigismund Chapel. The Virgin Mary, Saint Joseph, and the Infant Jesus are accompanied by angels and by shepherds bowing in honor to the Three Kings.

The Kraków nativity scene is a variant of Christmas nativity-scene constructions and as such can be seen as an example of religious art. It is undoubtedly viewed thus by many craftspeople. I remember a workshop for children during which the craftswoman explained the essence of the Kraków nativity scene to the children in these words:

As we know from the Holy Book, Lord Jesus entered the world in a lowly stable, because there was no room at the inn. But here in Kraków, we want to give the Lord Jesus what is most beautiful in our city - our historical buildings, palaces, and churches. That's what has brought about the Kraków nativity scene.

Regardless of the individual convictions of the makers, it may be observed that in presenting the scene of Jesus Christ's birth in the scenery of a mythologized Kraków, the Kraków nativity scene is sanctifying Kraków. The nativity scene tells of Christmas, but even more, it speaks of Kraków.

\section{BEFORE INSTITUTIONALIZATION: \\ THE NATIVITY SCENE AS A MOVEABLE CHRISTMAS THEATER}

In reviewing the history of the Kraków nativity-scene craft, it is impossible not to notice that it is divided into two stages. The first is the period when there was a dominance of constructions used in connection with Christmas caroling, when the construction served as a moveable puppet theater for the presentation of Christmas scenes in the homes of wealthy Cracovians. The second period began with the

in which many historical buildings and monuments testifying to Poland's past have been preserved - a city of churches and saints. Contemporarily, this is also homage paid to the tradition of the Kraków nativity scene. 
organization in 1937 of a competition for the most beautiful nativity scene'. This was the period in which the competition nativity scene came to dominate. These constructions referred to their predecessors but they were intended for a different kind of aesthetic reception. The oldest preserved Kraków nativity scene is located in the collections of the Seweryn Udziela Ethnographic Museum in Kraków. It was made in the 1890s by the tiler Michał Ezenekier from Krowodrza.

The tradition of the Kraków nativity scene derives from the nativity-scene figures which St. Francis popularized in Italy and which were brought to Poland by Franciscan monks. As Roman Reinfuss writes (1958), in the beginning these figures were presented in churches during the Christmas period as they were in the Easter period, that is, in side altars or chapels, against a stylized background of the Holy Land. With the passage of years, the number of figures in the decorations of individual churches rose, and the figures began to acquire secular traits.

The next stage in the development of the figures consisted in setting them in motion. This innovation coincided with the appearance in Poland of puppet theaters. The presentation of the figures, which still occurred in churches, produced great interest in the faithful. However, an increasing amount of secular and not necessarily pious content found its way into the scenes, to lively reactions of the viewing crowd. In response to the recurrence of inappropriate incidents in churches, the spiritual authorities forbade the showing of moving figures. The presentations thus began to be organized outside of churches, "and the nativity scene's period of splendid, unhindered development began from the moment it was ignominiously kicked out of the church and found itself in the street" (Reinfuss 1958, p. 9).

At the turn of the twentieth century, the creators of Kraków nativity scenes were craftsmen, especially masons, who in the autumn and winter seasons had a greater amount of free time. They lived in what were then the suburbs of Kraków: in Krowodrza, Czarna Wieś, Zwierzyniec, Grzegórzki, and Ludwinów. Reinfuss mentions that two types of nativity scenes were made: the larger kind, with a stage for puppet shows, and smaller ones, which were bought as souvenirs and trinkets. Bands of craftsmen, composed of several persons playing musical instruments, would gather around a nativity. At Christmas time, the groups set themselves up on the market square, between Floriańska and Św. Jana streets, and offered their shows to rich Cracovians. The band led by Michał Ezenekier was especially valued, but the bands of Walenty Malik and Władysław Owsiński were also popular ${ }^{10}$.

Cracovians' interest in the nativity scene shows and the competition among the teams resulted in the perfection and enrichment of the artistic style of the Kraków nativity scenes. Both the large nativity scenes, which served as puppet theaters, and the medium-sized nativity scenes, which were used while carol-singing, were popular.

9 The competition is known by several names, used interchangeably: the Competition for the Most Beautiful Kraków Nativity Scenes, the Competition for the Most Beautiful Kraków Nativity Scene, the Competition for Kraków Nativity Scenes.

${ }^{10}$ Karol Estreicher has a moving description of Ezenekier's nativity scenes and musical performances (1957, pp. 126-127). 


\section{INSTITUTIONALIZATION: THE PHENOMENON OF THE COMPETITION NATIVITY SCENE}

Unfortunately, the First World War and the death of many nativity-scene makers on the front interrupted the development of nativity-scene tradition. Technological changes, including the spread of cinema, which reduced the demand for puppet theater presentations (Reinfuss 1958), were also significant. Given the potential danger that the tradition of building nativity scenes would disappear and also to raise the artistic level of the small souvenir nativity scenes, the Kraków Municipal Council decided to undertake protective and promotional activities. The most important of these was the announcement of a competition for the most beautiful nativity scene. The first such competition took place on December 21, 1937. From the critical standpoint, the date is unusually important, because it marks the moment at which the institutionalization of the Kraków nativity-scene craft began. In the press bulletin announcing the event, there is a clear reference to the Kraków nativity-scene craft as a thing of value which should be protected, promoted, and developed (Kraków Museum Archives: after Szałapak 2012, p. 196). A separate competition was planned for carol singers, but it did not catch on and was abandoned after the second edition.

The panel of jurors for the first competition consisted of six people, including historians, ethnographers, artists, publicists, soldiers of the Polish Legions, or heads of Kraków academic and cultural institutions. A special figure in this group was Dr. Jerzy Dobrzycki, the initiator of the nativity-scene competition and of Kraków Days, and an indefatigable amateur of Kraków traditions. In the years 1934-1939 he was the director of the Municipal Office of Artistic Propaganda; from 1946 he was the director of the Historical Museum of the City of Kraków. In the competition, one first prize was awarded, two second prizes, three third prizes, four fourth prizes, one fifth prize, and honorable mentions ${ }^{11}$.

Successive editions of the competition brought lesser or greater changes in the regulations (Szałapak 2012,p. 221). For example, since 1972, the nativity scenes have been judged in three groups depending on size: large, medium, or small. In 1978, it was noted that there was a need to have separate categories for the nativity scenes made by adults (seniors) and by children and teenagers. Twelve years later, in 1984, an additional group was added for the jurors' evaluation: miniature or souvenir nativity scenes. In 2017 another category was introduced: the family nativity scene, as the experience of the previous years had shown that many nativity scenes that were entered as "children's" work in the competition had been made by adult hands. The

${ }^{11}$ At present, the winners of the competition receive financial awards, diplomas, and minor souvenirs; all the children taking part receive diplomas, books, stationery items, and museum souvenirs. In the first competitions, which took place just before the Second World War, and in the competitions just after the war, financial awards were also given, as well as material ones, according to the business profiles of the sponsors: wine, cakes, strudels, gingerbread, sausages, tramway tickets, books, a subscription to the journal Przekrój (see Niechaj [publication proposal] 2017; Wroński 1973). 
establishment of a family nativity-scene category had the added advantage of promoting the nativity-scene craft as a form of spending free time involving the entire family. The category immediately aroused considerable interest.

The current rules (IS 2) provide for the judging of nativity scenes in four main categories: seniors (creators over 18 years of age); family; youths (15-18 years); and children, divided into three subcategories - (I) children to age 8 , (II) children between 8 and 11, and (III) from 11 to 14 . The seniors' nativity scenes are divided in four groups: large - above 120 centimeters in height; medium - from 70.01 to 120 centimeters in height; small - from 15.01 to 70 centimeters in height; and miniature - to 15 centimeters in height. Experience shows, however, that small nativity scenes are often judged in the miniature group, if in the opinion of the judges they are of "the miniature type."

Over the course of more than eighty years in which the competition has been held $^{12}$, many outstanding Kraków citizens - people from the world of academe or art and culture - have sat on the panel of jurors. Among them can be mentioned the architect Prof. Franciszek Mączyński, the writers Dr. Jan Sztaudynger and Stefan Otwinowski, the ethnographer Prof. Tadeusz Seweryn, the painter and graphic artist Prof. Witold Chomicz, the historian Prof. Jan Pachoński, the architect Prof. Wiktor Zin, the legendary chief editor of Tygodnik Powszechny, Jerzy Turowicz, the ethnographer Prof. Czesław Robotycki, the ethnographer and cabaret performer from Piwnica pod Baranami, Dr. Anna Szapałak, the historian Prof. Jerzy Wyrozumski, and the ethnographer and museologist Prof. Jan Święch. Since 1946 the chairman of the competition's panel of jurors is the director of the Historical Museum of the City of Kraków: the first was Jerzy Dobrzycki, followed by succeeding directors (Michał Niezabitowski has held the position since 2015).

The competition panel, in appraising the nativity scenes, takes into account several criteria: their traditionality, architecture, color scheme, figures, narrativity, moving elements and light, innovativeness, decorativeness, and general aesthetic impression. The results of the competition are announced by the local media, and the winners, especially in the seniors' category, give many press and television interviews. During the succeeding weeks all the nativity scenes entered in the contest are shown in a post-competition exhibition, which draws visiting crowds from Kraków, the rest of Poland, and abroad.

In the nearly eighty-year history of the Kraków nativity-scene competition the increasing formalization of the rules of the competition, with their greater restrictiveness and detailed nature, is very clear. On the other hand, it is worth pointing out that until 2017 the combined rules of the competition occupied scarcely one page, and all additional questions were regulated by tradition. It was only in 2018 that the organizers were forced to change the rules in order to include provisions conforming with the new EU decree on the protection of personal data. The course of the

${ }^{12}$ In 2018 the 76th edition of the Kraków nativity-scene competition was held. The first competition took place in 1937 but the competitions were not held during the Second World War. 
competition itself was significantly influenced. The necessity of filling in a larger number of forms, particularly in regard to under-age nativity-scene makers, hampered the work of both the competition's participants and its organizers.

\section{THE TRADITION OF THE COMPETITION AND THE CANON OF KRAKÓW NATIVITY SCENES}

As early as 1958 Reinfuss wrote (p. 22) that "The annual nativity-scene review [...] can not fail to effect their development," and further,

During the past ten years, in which there have been annual nativity-scene competitions in Kraków, in addition to the above-mentioned small nativity scenes for children, the slightly larger ones for carol singers, and the large ones with puppets, a new kind of nativity scene has been born - one built especially for the competition. This youngest version, which stands out both for its perfection of form, richness of decoration, and masterly execution, today represents the Kraków nativity scene (Reinfuss 1958, p. 27).

We have to agree with Reinfuss; contemporarily, when we speak of the Kraków nativity scene we primarily have the competition nativity scene in mind. However, the competition nativity scene grew out of the nativity-figure tradition in Kraków and remains, to a certain degree, a continuation of that tradition, even if the impulse for its development was a top-down decision of a political and cultural nature: the idea of organizing the competition. Anna Szałapak writes that:

the Competition for the Most Beautiful Kraków Nativity Scene, which began in 1937, created the phenomenon of the Kraków nativity scene built especially for the occasion. [...] Over the course of these years, the competition and nativity scene have undergone various metamorphoses. In spite of changing fashions and events, the Kraków nativity scene has managed to retain its character and traditional canon (2002, p. 208).

The shape of the competition nativity scenes was affected not only by the jurors' decisions (such as the above-mentioned changing rules of the competition) but also by the very fact of rivalry between the makers. Maciej Moszew, who is known for his complicated mechanisms and moving figures and has won multiple competitions in the medium and small size categories, says that:

This rivalry provides the opportunity for a certain development. I have at home a nativity scene I made for 1981 - third prize - I'd be ashamed to show it today. The nativity scene I made this year has to be better. Well, I don't know if it will be that good - we'll see what the jurors say. [...] First place - that's mobilizing. You have to keep at that level. Did I aim for it? Of course. That's why I enter the competition. I think everyone - from those little ones to the older ones - are entering in order to win a prize (Merecik et al. 2017).

The jurors are guided by the rules in deciding on the winners of the competition, but they are also guided by their personal preferences and sense of what constitutes the canon of Kraków nativity scenes, which in turn is conditioned by their education 
and profession. As can be perceived in a media interview given by one of the jurors, Prof. Jan Święch, an ethnologist and museologist,

There are sometimes differences of opinion. But they arise primarily from the juror's occupation. The ethnographers sitting beside me practically do not differ in opinion, even though we were working separately, because we place strong emphasis on tradition in the nativity scene. There are professors here from the Academy of Fine Arts; they rather place the emphasis on artistic qualities... on a general appraisal, the impression [...] And there are architects, well, who analyze the architecture of the Kraków nativity scene very closely, and if there is some error, the appraisal goes down on the spot. And I think it's good that there are occupational groups here, thus the average gives a fair result (Merecik et al. 2017).

In theory, the jurors are not supposed to know who the maker of a given nativity scene is, but in practice it varies, especially in regard to the nativity scenes made by seniors. Before the meetings of the competition jury, the nativity-scene makers present their work at the feet of Adam Mickiewicz's statue. Moreover, the styles of the most well-known nativity-scene makers are easily recognizable by persons who have a keen interest in the craft.

The appraisal of the jurors and the history of those appraisals has had a clear influence on shaping the nativity-scene tradition. Szałapak mentions the fact (2012, p. 219), and Reinfuss had written about it earlier as well:

If a new form meets with the recognition of the competition jury and wins one of the first prizes, the other nativity-scene makers will try to refer to it, either in the proportions of their nativity scenes, or in the general silhouette, or only in certain details and characteristic decorative elements. In this way, the individual style of the nativity-scene maker is propagated and begins something that could be described by the name of a "school" (Reinfuss 1958, p. 27).

Święch confirms the fact:

It weighs on us that if we give a nativity scene very high points, then some of the nativity-scene makers will strive to copy those first prizes and later we will have a deluge of a certain convention that was given a prize. Well, and we try to combat this. We try to ensure that our appraisals are so fair that they will distinguish those who, on the one hand, maintain the tradition, and on the other hand, introduce certain innovative narratives, because after all, the world is changing (Merecik et al. 2017).

At the same time, it is worthwhile to observe that the verdict of the competition panel elevates one kind of nativity-scene and suppresses others. Sometimes the votes of the jurors are divided, and every detail is intensely discussed. Very often, innovations by the nativity-scene makers produce strong emotions. Szałapak (2012, p. 219) remembers a discussion evoked by the introduction of a new material to the construction of the nativity scenes: thin sheets of colored metal instead of tinfoil. The above-mentioned film from the Jubilee $75^{\text {th }}$ Kraków Nativity-Scene Competition in 2017 (Merecik et al. 2017) looked behind the curtains at the sessions of the competition panel and showed current-day disputes over the essence of the Kraków nativity scenes. In the film, a discussion - and also the clear disapproval of the jurors - is evoked by a nativity scene that is actually an example of conceptual art and in addition a response to current political and social events, with only a subtle 
reference to the tradition of the Kraków nativity scenes. The disapprobation of the jurors was also aroused by nativity scenes made out of Lego blocks, though these produced considerable enthusiasm on the part of the child spectators (I write this as a guide to the post-competition exhibitions of nativity scenes). As Witold Turdza, one of the jurors, summarized the matter,

The nativity-scene makers try to go with progress and to introduce what is called innovation. They understand it differently and, for instance, it has happened that in the nativity scenes some piece of industrial architecture appeared in the nativity scene - that there were chimneys instead of towers. On the other hand, that's always been there in the nativity scene, especially in the presentations of nativity figures, those intermedia, referring to current events - it's often expressed in the form of bringing in elements that don't at all fit the traditional nativity scene. And it often clashes with the nativity scene. Perhaps someday it will all even out and the nativity-scene makers will be able to harmonize the tradition with that kind of innovativeness, but for the moment it's often out of place. For me, for instance, that's often not a nativity scene at all (Merecik et al. 2017).

\section{Anna Beiersdorf agrees with him:}

Nativity-scene makers try to change. But nevertheless that traditional nativity scene is the most beautiful. Some attempts at change, well, they aren't going in the right direction. If nativity-scene makers keep the nativity-scene tradition and somehow enrich that nativity scene, then it's really good, but if they introduce elements that are entirely distant from Kraków's architecture - and that happens - then it's no longer good (Merecik et al. 2017).

An unfavorable decision by the judges sometimes causes nativity-scene makers to feel insulted and to withdraw from participation in competitions or, at least, to express their bitterness (cf. Fryś-Pietraszkowa 1972, p. 57). On the other hand, it is not out of the question that the Kraków nativity-scene craft would not survive if it were not for the tradition of the competitions (Fryś-Pietraszkowa 1972, p. 57). The atmosphere of competing and the chance for a prize has mobilized succeeding generations of nativity-scene makers to intensive work and to finishing by the deadline, but an unfair appraisal by the jurors may cause a nativity-scene maker to stop competing in the future and sometimes in general to relinquish the hobby.

It might appear that the power of the jurors can only affect the nativity-scene makers, but it emerges that the jurors themselves are not free from troublesome dilemmas. According to the rules, only those nativity scenes are eliminated that lack elements of the Christmas scene (even if limited to the Infant Jesus). The remaining criteria of the rules for appraisal are simply guidelines and must be interpreted by the jurors.

I admit that in the period when I was working in the Kraków Museum and actively engaged with Kraków nativity scenes, I more than once wondered whether it wouldn't be a good idea to create a separate competition category for "unorthodox" or "noncanonical" nativity scenes, which are only loosely connected with the traditional Kraków nativity scenes. At the moment there is nothing to indicate that the competition panel is going to make such an addition, but the fact is that every year this type of nativity scene is brought to the competition. The makers of such nativity scenes are rather not counting on winning the highest awards, but they hope their work 
will not pass without notice by the public gathered first by the Mickiewicz's statue and later at the post-competition exhibition (at which all the competition entries are shown). In recent years, this has been the case with the nativity scenes made out of jelly or Lego blocks, the nativity scene in the form of embroidery on a Kraków-type corset, the nativity scene in a bullet-pierced helmet, the anti-smog nativity scene...

To complete the argument, one more piece of information should be added. In the period of most severe communist repression, the regime influenced the attitudes of the judges and makers and thus also influenced the Kraków nativity scenes. Szałapak (2012, p. 217) remembers that the communist authorities made efforts to remove the Christmas accents from the Kraków nativity scenes and to keep the architectonic values, and many nativity-scene makers submitted to that ideology.

In finishing this part of the article, it should be noted that from the beginning of the competition the group of jurors has predominantly been composed of people who deal with issues connected with Kraków's heritage on a daily basis (ethnographers, historians, art historians, museologists, academics, city officials, politicians). Over the course of the competition's history, the authors of nearly all the publications on Kraków nativity scenes and the promulgators of many initiatives connected with making nativity scenes (including inclusion on the UNESCO list) have come from the group of jurors. Thus it is possible to claim that these persons are co-creators of Kraków’s nativity-scene heritage.

\section{UNESCO-IZATION: THE NATIVITY SCENE (SZOPKA) TRADITION IN KRAKÓW ON UNESCO'S REPRESENTATIVE LIST OF THE INTANGIBLE CULTURAL HERITAGE OF HUMANITY}

Over sixty years ago, Reinfuss wrote that the Kraków nativity scene "in its present form has lost the function it fulfilled in the customs of the Christmas season, and it has not found a new use that would be a basis for its further development" (1958, p. 22). It seems to me that today the professor would reach a different diagnosis. While it might be agreed that the majority of the traditional Christmas functions of the Kraków nativity scene have been irretrievably lost, the range of uses for the nativity scene has clearly been expanded. In 1975, the Department of Folklore and Krakow Tradition was established in the Historical Museum of the City of Kraków (Szałapak 2012, p. 211). The tasks of the Department's employees include preserving and promoting two well-known city traditions: the Kraków nativity scenes and the Lajkonik procession. The Museum has a collection of over 300 Kraków nativity scenes and is the organizer of the annual competition and post-competition exhibition, with accompanying events (for instance, meetings with the nativity-scene makers, nativityscene workshops for children, films about the nativity-scene makers, auctions of the nativity scenes, and integration meetings for the nativity-scene makers).

In addition, every year nativity scenes are loaned for exhibitions within the country and abroad. For the past four years the Museum has been working with the 
Kraków Festival Office in the winter season to place nativity scenes in the windows of Kraków shops, restaurants, and service outlets and in external displays in parks and squares, and along avenues. Most of these nativity scenes come from museum collections, but in addition there are some that were commissioned by the Museum especially for the purposes of external presentation. They are made of more durable materials and are intended to be viewed from behind as well. On Epiphany, on January 6, the director of the Museum leads a walk around the nativity scenes. Special publications, describing each point on the walk in detail, are prepared for the event. All these events are intensively promoted and announced in the media. The majority meet with considerable interest.

As Michał Niezabitowski, the current director of the Kraków Museum, states,

We have managed to arrive at the point where the nativity scene is going back where it came from. Basically, the nativity scene came from the street. The nativity scene is the child of the Kraków street. The first Kraków nativity scenes were the small theaters of fellows from Zwierzyniec, from Krowodrza, who recreated the Christmas scene in such theaters inspired by Kraków architecture, with additional texts to actualize the scene (Merecik et al. 2017).

The Kraków nativity scene thus exists in the Kraków Christmas scenery, but in a new manner. At the same time, it has a major promotional use for the Kraków Museum and for the city itself (see Kwiecińska 2017).

The senior Kraków nativity-scene makers are a group of around 50 persons, who are not affiliated with any formal association ${ }^{13}$, but are strongly connected with the Kraków Museum. When the Ministry of Culture and National Heritage undertook to enter the Kraków nativity-scene craft on the Representative List, the Museum was enlisted in the role of an expert. The Museum employees (whose backgrounds are in ethnology and history) had a major part in writing the application and in organizing consultations with the nativity-scene makers. It is worth noting here that the procedure for entering a phenomenon on the representative list involved multiple stages and required the careful preparation of an application and appendices ${ }^{14}$. In connection with these formal activities, the funds allocated for the organization of the competition and the promotion of the Kraków nativity-scene craft were increased. The source of

${ }^{13}$ Perhaps the atmosphere of competition rivalry does not favor the emergence of a nativity-scene makers' society. Ewa Fryś-Pietraszkowa speaks of the nativity-scene makers' club that was established on the initiative of the director of the Historical Museum of the City of Kraków toward the end of the 1960s, but it did not last long (Fryś-Pietraszkowa 1972, p. 58).

${ }^{14}$ It should be added that the Lajkonik tradition has similarly been the focus of the Kraków Museum's care. The Museum not only organizes the annual procession but also acted as an expert in the successful attempts to have the Lajkonik parade entered on the Polish Intangible Cultural Heritage List. Zbigniew Glonek, who has played the role of the Lajkonik for the past thirty years, does not hide his disappointment that the nativity-scene makers found themselves on the UNESCO Representative List first, and reminds people that the Lajkonik procession is waiting in line. Hafstein (Hafstein 2009: 108), among others, draws attention to the problem of selecting the phenomena to be included on the list. More information on the creation of intangible cultural heritage using the example of the Lajkonik procession and the role of experts in the process of forming heritage can be found in the work of Andrzej Iwo Szoka (Szoka 2016). 
the subsidy was the City of Kraków, but in recent years the Ministry of Culture and National Heritage, which was impressed by the application submitted by the Historical Museum of Kraków in the Folk Culture program, has also provided funds.

Reading the application for entry on the UNESCO list gives a view of the expectations of the nativity-scene makers and of the institutions working with the milieu in regard to the future of the Kraków nativity-scene craft. Interestingly, in the application and appendices, information about the annual Kraków nativity-scene competition as an important element in preserving and shaping the craft was shifted to the background in order to emphasize the long duration of the tradition itself, based on intergenerational transmission, and the tradition's openness to persons of various sex, age, education, religion, occupation, social origin, and financial standing. In the application, it was also highlighted that the tradition of building nativity scenes favors the development of the imagination and skills of the creators. Strong emphasis was placed on the importance of the tradition in building interpersonal ties and deepening and transmitting knowledge about Kraków. The arguments included in the application, such as the plan for protecting the Kraków nativity-scene craft, convinced the UNESCO committee to accept the craft's inclusion on the list.

The plan for safeguarding the craft contains a list of the present and potential dangers identified by nativity-scene makers:

a) possible negative side effects related to the visibility and public attention resulting from the inscription;

b) the lack of space at home to store the annually-made cribs;

c) difficulties with obtaining good (according to makers) quality materials for the construction of the cribs. This is tied to the gradual lowering of its quality as a result of replacing traditional methods of its production with new technologies;

d) the imbalance between the numbers of adult and young bearers, who could continue the tradition;

e) the risk of decontextualisation of the Christmas setting of this tradition in the case of a potential increase of interest in it stemming from the inscription;

f) the lack of means and skills to represent the works of every crib maker;

g) the lack of knowledge and awareness tied to intellectual property rights and associated legal issues and procedures;

h) the lack of precise legal regulations aimed at comprehensive safeguarding of $\mathrm{ICH}$ in Poland;

i) the risk of abusing the traditional customs for economic gains. (IS 1, pp. 8-9)

In answer to these fears individual cultural institutions (including the Ministry of Culture and National Heritage, the National Heritage Institute, the Małopolska Voivodeship, the Department of Culture and National Heritage of Kraków City Hall, the Historical Museum of the City of Kraków, the Seweryn Udziela Ethnographic Museum in Kraków, and the Friends of Kraków's History and Historical Monuments Society) have shouldered a series of obligations. Some consist in maintaining the usual activities while others are more innovative in nature. They include monitoring the phenomenon after its inclusion on the UNESCO list, continuing the tradition of 
the annual competition, organizing nativity-scene workshops for children, publishing works on nativity-scene-making for children, creating an internet site (a kind of encyclopedia of the Kraków nativity-scene craft), and subsidizing the purchase of materials for making nativity scenes. One of the obligations is to create a municipal nativity-scene workshop, which would provide a workplace and a storage space for the nativity scene makers, but also a place for the presentation and sale of nativity scenes, especially in the Christmas season. Legal proceedings in this regard were commenced at the beginning of 2019 , but so far without success ${ }^{15}$.

The inclusion of the nativity scene tradition in Kraków on UNESCO's Representative List of Intangible Heritage began a new stage in the craft's history, which after David Berliner could be called its UNESCO-ization. As Chiara De Cezari (2013, p. 402) has stated, this is a form of cultural globalization.

It is too early to draw far-reaching conclusions about the influence of the UNESCO Committee's decision on the shape of the Krakow nativity-scene craft, nevertheless a few indicators of possible directions of change can already be observed. First, the announcement and then acceptance of the application met with considerable media interest. Naturally, this was also partially due to the marketing policy of the Kraków Museum. It is to be expected that if the annual interest is maintained there will be a growing need to organize exhibitions of Kraków nativity scenes, and the competition itself and the post-competition exhibition will attract an even more numerous audience.

Perhaps, in accord with the hopes of the nativity-scene makers, there will also be more people and institutions interested in purchasing the nativity scenes ${ }^{16}$. It is hard to say, however, whether there will be any growth in the number of nativity-scene makers, especially among the adults. Second, the process of applying for inclusion promoted thinking of the Kraków nativity-scene tradition in categories of a "phenomenon" of "intangible cultural heritage," and of naming the nativity-scene makers its "depositors." Such naming practices, which would seem fairly foreign to the nativity-scene makers themselves, are very strongly present in the narrative of the Kraków Museum. Furthermore, the process has introduced the term "Krakow

${ }_{15}$ The amendment of the resolution concerning the City of Kraków's financing of workshops provides for the possibility of renting a workshop by non-professional craft makers but only when their craft activity does not constitute their main source of livelihood (IS 3, p. 3). It would seem that no Kraków nativity-scene builder meets the second condition. On the other hand, it is worth pointing out that in 2019, for the first time, two nativity-scene makers applied for a City of Kraków Creative Stipend for the competition and both received the grant.

${ }_{16}$ The risk of commodifying the tradition (see Węglarska 2013, pp.94-95), as well as the appearance of fakes of the Kraków nativity-scenes (among other things, as the nativity-scene makers have frequently pointed out, in the form of cheap mass produced fake nativity scenes being sold as "souvenirs from Kraków"). Jacek Puchla, in analyzing questions connected with managing heritage, looks at the problem with greater optimism: "Heritage [...] must be treated not only as sacrum but also as a good; as such it is subject to the laws of economics and there is no need to shamefully hide this fact. It is in the conditions of ongoing globalisation that heritage becomes an ever more attractive resource and factor of development" (Purchla 2005, p. 57). 
nativity-scene craft" (szopkarstwo krakowskie), which earlier was practically not used in Poland either in the literature or in everyday speech. It would not be an exaggeration to state that the term came into use for the need of preparing the application for inclusion on the National List and then on UNESCO's Representative List, in order to emphasize the intangible dimension of the nativity-scene craft. The result of these efforts is a certain inconsistency in the nomenclature, which is perceptible even in the statements of people responsible for the correctness of the message. Some of the employees of Kraków Museum, even in public statements, erroneously repeat that the Kraków nativity scenes were entered on the UNESCO list. Other people involved in educating museum-goers and the media emphasize that the Kraków nativity-scene craft was entered on the list, and they explain that what is involved is more than just the nativity scenes themselves.

Although shifting attention from the nativity scene to the craft is characteristic of formalization, from an anthropological viewpoint it could turn out to be cognitively fruitful. As Amanda Kearney has said, appreciation of the intangible side of cultural heritage facilitates looking at spheres of heritage that have previously been omitted (see Kearney 2009, p. 222).

Third, the procedure for entering the Kraków nativity-scene craft on the National List and then on the UNESCO Representative List promoted the idea of the nativityscene craft as part of Kraków's heritage. The idea began to circulate first at the institutional level, in academic discourse and among nativity-scene makers, and then by the force of its popularization, in broader circles of recipients. A certain shift occurred: previously Kraków nativity scenes belonged to the sphere of phenomena described as Kraków's tradition or folklore (cf. Adell, Bendix, Bortolotto, Tauschek 2015, p. 7). The direction of change is clearly visible in the actions of the Kraków Museum, which on November 25, 2017 organized in the Celestat Museum an open "Meeting with Kraków's Intangible Culture," to which it invited, among other people, Kraków nativity-scene makers as speakers. The $15^{\text {th }}$ Congress of the Organization of World Heritage Cities was held in Kraków on June 2-5, 2019. Kraków nativity-scene makers also took part in the press conference preceding the Congress. It is worthwhile to note here that the engagement of the nativity-scene makers in the formal and promotional side of inclusion on the UNESCO list required - and still requires - more far-reaching skills than the nativity-scene craft. This was the moment when the nativity-scene makers were forced not only to make nativity scenes, but also to talk about them (for the media, at official meetings, in debates, and so forth).

Finally, inclusion on the list symbolically raised the prestige of the nativity-scene makers themselves. As Kwiecińska (2018) summarized the matter, "Inclusion is unusually important for the tradition itself and its promotion in the world, but primarily for the nativity-scene makers themselves, who felt appreciated in the international arena. More than one person said to me that it was the highest honor and award for them - a kind of Oscar for their creative passion."

The above examples confirm what Kocój wrote about mainstream heritage (2019): it is a privileged heritage, well financed and promoted from above, which therefore 
makes it the most visible kind of heritage in the social sphere. On the other hand, it should be emphasized that complicated bureaucratic procedures, the necessary effort of promotion, and increasing financial expenditures have a major significance for the creation of culture. As Meyer and van de Port write, "All these objects, places, and practices become 'heritage' through complex processes of institutionalization and undertaking political decisions" and, obviously, many "candidates" for becoming heritage do not receive recognition (Meyer, van de Port 2018, p. 7).

We are left with questions, though. Will the Kraków nativity scene craft, which has been to this time a rather local craft, come to be associated with the ambition of being raised to the level of national heritage, and if so, at what price? ${ }^{17}$ What political and ideological influences will the Kraków nativity scene craft be subjected to in the coming years? Will inclusion on the list lead to changes in the artistic form of the nativity scenes or rather to the preservation of their current state? How will the audience for the competition and exhibition change? What will it look for and find in the nativity-scene craft? And also - will there come to be conflicts between the various heritage policies in regard to the Kraków nativity-scene craft?

\section{CONCLUSION}

The events forming the history of the Kraków nativity-scene craft, of which we have material and written evidence from at least the nineteenth century, have included actions from above conducted by the City of Kraków, Kraków Museum, the Ministry of Culture and National Heritage, and UNESCO. A turning point in the history of the nativity scene craft was the competition in 1937 for the most beautiful Kraków nativity scene. The competition created the phenomenon of the so-called competition nativity scene, which has undergone succeeding transformations in response, among other things, to the decisions of the jurors. At the same time, the institutionalization and musealisation of the nativity scenes has proceeded (Meyer, van de Port 2018, p. 12). In 2018, the nativity scene tradition in Kraków was entered on the UNESCO Representative List of the Intangible Cultural Heritage of Humanity. It is to be expected that this fact will permanently mark the history of the Kraków nativity scene craft. As Janina Hajduk-Nijakowska (2013) mentions, formal preservation measures undertaken in regard to intangible cultural heritage never fail to affect what is protected. It should be noted that the definition of intangible cultural heritage adopted in UNESCO's plan of action, as well as in the schema adopted in the UNESCO Convention of 2003, has received numerous criticisms (see, for instance, Gentry, Smith 2019).

Today, it can certainly be said that the Kraków nativity scene competition, which interfered to such a large degree in the nativity scene - tradition, is in itself one of

${ }^{17}$ It is worth noting that a reverse process can occur too, when Kraków heritage or national heritage is seen, especially abroad, through the prism of Kraków nativity scenes (see Harrison 2009, p. 14). 
the most important of Kraków traditions ${ }^{18}$, and the Kraków nativity scene craft has been imbued with the heritage of the competition nativity scenes. However, this does not invalidate surprise at the vitality of the nativity scene craft. We have to agree with Niezabitowski that:

\begin{abstract}
The phenomenon of the nativity scenes is that they have lasted. After all, we do not commission these nativity scenes. Perhaps it might seem so to someone - that, for instance, every year the Museum orders 120 nativity scenes for the competition. No. From generation to generation - in some families those are the fifth or sixth generation - every year, around one hundred people in Krakow, or maybe even more, counting the smallest children, feel the need to spend several thousand hours a year in order to bring their own nativity scene to the competition (Merecik et al. 2017).
\end{abstract}

An anthropological look at the more than hundred-year history of the Kraków nativity scene craft reveals that the form we see now is the result of a series of changes in which there has been room for both artistic freedom of creation and decisions of a political and cultural nature.

\title{
LITERATURE
}

Adell Nicolas, Bendix Regina F., Bortolotto Chiara, Tauschek Markus 2015, Introduction [in:] N. Adell, R.F. Bendix, Ch. Bortolotto, M. Tauschek (eds.), Between imagined communities and communities of practice: Participation, territory and the making of heritage, Göttingen Studies in Cultural Property, Volume 8, Universitätsverlag Göttingen, pp. 7-21.

B a r c z e w s ki W i e sła w 2005, Szczypta kleju, trochę iluzji-czyli jak się robi szopkę Krakowska / A Bit of Illusion, Some Glue - or How to Make a Cracow-Style Crib, Dom Wydawniczy Rafael, Kraków.

B a r c z e w s ki Wi sław 2015, Skąd się wzięła szopka Krakowska?, Dom Wydawniczy Rafael, Kraków.

B e n dix Regin a 2009, Heritage between economy and politics: An assessment from the perspective of cultural anthropology, [in:] L. Smith, N. Akagawa (eds.), Intangible heritage, Routledge Falmer, London and New York, pp. 253-269.

D e C e z a r i C h i a r a 2013, Thinking through heritage regimes, [in:] Heritage regimes and the stat 6, Universitätsverlag Göttingen, pp. 399-413.

E s t r e i ch e r K a r o 1 1957, Nie od razu Kraków zbudowano, Państwowy Instytut Wydawniczy, Warsaw.

Fr y ś-P i e tr a s z k o w a E w a 1972, Szopkarze Krakowscy a konkursy szopek, Polska Sztuka Ludowa - Konteksty 1972, vol.26, z. 1, pp. 57-58.

Gentry Kynan, Smith Laurajane, Critical heritage studies and the legacies of the late-twentieth century heritage canon, International Journal of Heritage Studies, vol. 25, issue 11, pp. $1148-1168$.

$\mathrm{H}$ a f s t e in Vald i m a r Tr. 2009, Intangible heritage as a list: From masterpiece to representation, [in:] L. Smith, N. Akagawa (eds.), Intangible heritage, Routledge Falmer, London and New York, pp. 93-111.

${ }^{18}$ A direct proof is the fact that many Krakovians were displeased about the moving - temporarily! - of the exhibition in the years 2017-2019 from the Krzysztofory Palace (the main branch of the Kraków Museum) to the Celestat (another branch of the Museum) because of renovations. The organizers tried hard to ensure that in spite of the change none of the traditional points in the competition program were omitted (for instance, the nativity scene makers march with their productions from the Mickiewicz statue to the branch of the Kraków Museum where the works are judged and prepared for exhibition. 
Hajduk-Nija kow ska Ja n in a 2013, Ochrona dziedzictwa czy postfolkloryzm narodowy? [in:] J. Adamowski, K. Smyk (eds.), Niematerialne dziedzictwo kulturowe: źródła - wartości - ochrona, Wydawnictwo UMCS, Narodowy Instytut Dziedzictwa, Lublin-Warsaw, pp. 65-74.

Harris o n R o d n e y 2009, What is heritage? [in:] R. Harrison (eds.), Understanding the politics of heritage, Manchester University Press, Manchester, pp. 5-42.

Ke a r n e y A m a n d a, Intangible culture heritage: Global awareness and local interest, [in:] L. Smith, N. Akagawa (eds.), Intangible Heritage, Routledge Falmer, London and New York, pp. 209-225.

Ko có j E wa 2019, Między mainstreamem a undergroundem. Dziedzictwo regionalne w kulturze europejskiej - odkrywanie znaczeń, [in:] E. Kocój, T. Kosiek, J. Szulborska-Łukaszewicz (eds.), Dziedzictwo kulturowe $w$ regionach europejskich. Odkrywanie, ochrona i (re)interpretacja, publication series: Studia nad dziedzictwem i pamięcią kulturowa, vol. I, Jagiellonian University Press, Kraków, pp. 19-38.

Krupski Jan [St anisław Estreicher] 1904, Szopka Krakowska, Czcionkami Drukarni Czasu, Kraków.

Kwiecińska Magdalena, Niechaj Małgorzata 2012, Portrety twórców szopek Krakowskich, Muzeum Historyczne Miasta Krakowa, Kraków.

Kwie cińska Magda len a 2016, Szopkarstwo Krakowskie - tradycja pokoleń. Działania Muzeum Historycznego Miasta Krakowa na rzecz ochrony niematerialnego dziedzictwa kulturowego miasta, [in:] Narracja, obyczaj, wiedza... O zachowaniu niematerialnego dziedzictwa kulturowego, eds. A. Przybyła-Dumin, Muzeum Górnośląski Park Etnograficzny w Chorzowie, Wydawnictwo Uniwersytetu Marii Curie-Skłodowskiej, Narodowy Instytut Dziedzictwa, Chorzów - Lublin - Warsaw, pp. 169-182.

Kw i e c ińska Mag dalen a 2017, Szopkarstwo Krakowskie w procesach kształtowania dziedzictwa miasta, Zeszyty Naukowe Uniwersytetu Jagiellońskiego. Prace Etnograficzne 2017, vol. 45, z. 3, pp. 333-350.

Kw i e c ińska Magda le na 2018, Sam Wyspiański zachęcał Krakowskich szopkarzy do inspirowania się architektura miasta (interview), https://dzieje.pl/aktualnosci/dr-kwiecinska-sam-wyspianskizachecal-Krakowskich-szopkarzy-do-inspirowania-sie, accessed 9.04.2019.

Ludwikowski Leszek, Wroński Ta de us z 1978, Tradycyjna szopka Krakowska, Muzeum Historyczne Miasta Krakowa, Krajowa Agencja Wydawnicza, Kraków.

Meyer Birgit, van de Port Mattijs 2018, Introduction, [in:] B. Meyer, M.van de Port (eds.), Sense and essence: Heritage and the cultural production of the Real, Berghahn Books, New York - Oxford, pp. 1-39.

Niechaj Małgorzata [publication proposal] 2017, Konkursy szopek Krakowskich 1937-2017, Muzeum Historyczne Miasta Krakowa, Kraków.

Oles zki ewicz Małgor zat a 2008a, Między rekwizytem kolędniczym a apoteozą miasta - fenomen szopki Krakowskiej, [in:] R. Godula-Węcławowicz (ed.), Miasto w obrazie, legendzie, opowieści..., Polskie Towarzystwo Ludoznawcze, Uniwersytet Wrocławski, Wrocław - Kraków.

Oles zki ewic z Małgor zat a 2008b, Szopka mistrza Ezenekiera. Mity, pytania i okruchy prawdy o pewnej szopce z końca XIX wieku, Rocznik Krakowski, vol. 74, pp. 173-182.

P łate k P i ot r 1971, Szopka Krakowska. Okolędowania, Kraków.

P u rchla Jacek 2005, Dziedzictwo a transformacja, Międzynarodowe Centrum Kultury, Kraków.

Re infus s Rom a n 1958, Szopki Krakowskie, Wydawnictwo Artystyczno-Graficzne RSW Prasa, Kraków.

Rydel Lucjan 1983, Betlejem polskie, PWM-Edition, Kraków.

$\mathrm{S}$ z a ł a p a k A n n a, Szopka Krakowska jako zjawisko folkloru Krakowskiego na tle szopki europejskiej. Studium historyczno-etnograficzne, Muzeum Historyczne Miasta Krakowa, Kraków 2012.

S zoka Andrzej Iwo 2016, Pochód Lajkonika. Między tradycją a kreacją, [in:] M. Kwiecińska (ed.), Niematerialne dziedzictwo miasta. Muzealizacja, ochrona, edukacja, Muzeum Historyczne Miasta Krakowa, Kraków, pp. 256-269. 
Węglarska Ka mila 2013, Niematerialne dziedzictwo kulturowe w kontekście marketingowym - szanse i zagrożenia, [in:] J. Adamowski, K. Smyk (eds.), Niematerialne dziedzictwo kulturowe: źródła - wartości - ochrona, Wydawnictwo UMCS, Narodowy Instytut Dziedzictwa, LublinWarsaw, pp. 89-99.

Wrońs ki Ta d e u z 1973, Konkursy szopek Krakowskich, Muzeum Historyczne Miasta Krakowa, Kraków.

Z aw iła Małgor zata 2019, Dziedziczynienie przedwojennych cmentarzy na terenach postemigracyjnych Polski, Wydawnictwo Uniwersytetu Jagiellońskiego, Kraków.

\section{Internet sources}

https://ich.unesco.org/en/RL/nativity-scene-szopka-tradition-in-Krakow-01362 (wniosek o wpis szopkarstwa Krakowskiego na Listę reprezentatywną niematerialnego dziedzictwa kulturowego ludzkości UNESCO wraz z załącznikami i decyzją Komitetu ds. ochrony niematerialnego dziedzictwa kulturowego UNESCO), accessed 09.04.2019.

https://www.muzeumKrakowa.pl/images/upload/wystawy/wystawy_czasowe/2018/szopki/Regulamin2. pdf, accessed 09.04.2019.

https://www.bip.Krakow.pl/?dok_id=167\&sub_dok_id=167\&sub=uchwala\&query=id\%3D23877\%26typ \%3Du (Uchwała nr IV/74/19 Rady Miasta Krakowa z dnia 9 stycznia 2019 r. zmieniająca uchwałę Nr CXVIII/1249/06 w sprawie przyjęcia programu mecenatu artystycznego i usług publicznych w zakresie kultury - pracownie twórcze), accessed 09.04.2019.

http://Krakow.wyborcza.pl/Krakow/7,44425,24284299,kulisy-wpisu-szopkarstwa-na-listeunesco-ministerstwo-chcialo.html, accessed 01.06. 2019.

\section{Video material}

D a g m a r a M e r e c i k et al. (director) 2017, 75. Jubileuszowy Konkurs Szopek Krakowskich [The Jubilee 75th Kraków Nativity-Scene Competition], Historical Museum of the City of Kraków, 2017 (film on DVD).

\section{ALICJA SOĆKO-MUCHA}

\section{FROM “TRADITION” TO “INTANGIBLE HERITAGE”: KRAKÓW’S NATIVITY-SCENE CRAFT}

Key words: heritage-in-creation, heritagization, Kraków Nativity-Scene, Kraków, Polish Intangible Cultural Heritage List, UNESCO

The article presents three main stages in the history of the Kraków nativity-scene craft. First, the stage prior to institutionalization, covering the oldest history of nativity-scene making; second, the stage of institutionalization, initiated by the organization of the first competition for the most beautiful nativity scene in Kraków in 1937; and third, the UNESCO-ization of the nativity-scene craft, inaugurated by the inclusion of the Kraków nativity-scene (szopka) tradition on UNESCO's Representative List of the Intangible Cultural Heritage of Humanity in 2018.

Article translated by Michelle Granas

Author's Address:

Dr Alicja Soćko-Mucha

Institute of Archeology and Ethnology, Polish Academy of Sciences

ul. Sławkowska 17, 31-016 Kraków, Poland

E-mail: scribo@interia.pl

ORCID: https://orcid.org/0000-0001-9842-3017 